\title{
Changes in Rapidly Transported Proteins in Developing Hamster Retinofugal Axons
}

\author{
Kenneth L. Moya, ${ }^{1}$ Larry I. Benowitz, ${ }^{2}$ Sonal Jhaveri, ${ }^{1}$ and Gerald E. Schneider ${ }^{1}$ \\ 'Department of Brain and Cognitive Sciences, Whitaker College, Massachusetts Institute of Technology, Cambridge, \\ Massachusetts 02139, and 'Department of Psychiatry and Program in Neuroscience, Harvard Medical School, Boston, \\ Massachusetts 02115, and Mailman Research Center, McLean Hospital, Belmont, Massachusetts 02178
}

Proteins synthesized in retinal ganglion cells and conveyed to the terminals of optic tract axons in the rapid phase of axonal transport were analyzed at different developmental stages in the hamster. Animals between $2 \mathrm{~d}$ of age and adulthood were labeled intraocularly with ${ }^{35} \mathrm{~S}-$-methionine, and after a $4 \mathrm{hr}$ survival time, the superior colliculus was dissected out, subjected to subcellular fractionation, and radiolabeled proteins in the particulate fraction analyzed by 2-dimensional gel electrophoresis and fluorography. The previously identified growth-associated phosphoprotein, GAP-43 (GAP-48, B-50, F1, pp46), was synthesized and transported at high levels in the neonate, but these levels declined precipitously after the second postnatal week. Immunohistochemical studies using a monospecific antibody showed that GAP-43 was localized along the entire length of retinal axons in the optic tract and target areas in P2 animals but was virtually absent in the adult visual pathway. By metabolic labeling, 2 proteins with molecular weights of about $230 \mathrm{kDa}$ also showed a sharp decrease during development. In contrast, acidic proteins of 27 and $64 \mathrm{kDa}$, which were barely detectable in the neonate, increased steadily to become the most heavily labeled proteins of rapid axonal transport by the second postnatal week. Another group of proteins, of about 94-110 kDa, also rose to peak levels after birth but then declined. Temporal correlations between the molecular changes described here and the known anatomical events in optic tract development suggest that the synthesis and transport of particular membrane proteins may be directly related to the sequence of morphological changes.

The development of the nervous system is marked by the formation of precisc conncctions among subsets of neurons that are often separated by considerable distances. Molecular constituents of the nerve terminal plasma membrane are likely to play a major role in mediating many events that take place during this process, including axon guidance, target recognition, and the formation of end-arbors and synapses. Thus, the identification of specific proteins delivered to the growing tips of

Received Nov. 17, 1987; revised Apr. 15, 1988; accepted Apr. 28, 1988.

We would like to thank Dr. Vernon Ingram for valuable comments on an earlier version of the manuscript. This work was supported by an NSF Graduate Student Fellowship and NIH Grants EY00126, EY/NS05504, EY05690, and EY02621.

Correspondence should be addressed to Dr. Larry I. Benowitz, McLean Hospital, 115 Mill Street, Belmont, MA 02178.

Copyright (C) 1988 Society for Neuroscience $0270-6474 / 88 / 124445-10 \$ 02.00 / 0$ axons during critical stages of development is likely to contribute to our understanding of the biological mechanisms that underlie the formation and modification of synaptic relationships.

Many proteins destined for the nerve terminal membrane are synthesized in the perikaryon and conveyed down the axon in the rapid phase of axonal transport (Willard et al., 1974; Lorenz and Willard, 1978; Grafstein and Forman, 1980; Hammerschlag and Stone, 1982). Changes in this group of proteins have been described in a variety of developing and regenerating systems. Studies in regenerating optic nerves of lower vertebrates (Skene and Willard, 1981a; Benowitz and Lewis, 1983; Perry et al., 1987) and in regenerating mammalian peripheral nerves (Skene and Willard, 1981b; Redshaw and Bisby, 1984) have revealed the existence of rapidly transported proteins whose rates of synthesis are associated with the regrowth of nerve fibers. One of these proteins, GAP-43, has also been found in the normally developing CNS of rabbit (Skene and Willard, 1981 b), rat (Jacobson et al., 1986), and hamster (Kalil and Skene, 1986; Moya et al., 1987a), suggesting a possibly universal role in the formation of neuronal pathways.

In the present studies we have examined the time course of expression of a number of rapidly transported proteins in the developing hamster retinofugal pathway. Since many of the morphogenetic events have been previously charactcrized in this system, we are in a position to suggest correlations between protein changes and specific anatomical phenomena. In addition, the short gestation period (15.5 d) of the hamster makes earlier stages of neuronal development accessible in the neonate. Our results demonstrate a number of striking developmental changes, some of which have not been previously described. Each of the major rapidly transported proteins appears to have a characteristic ontogenetic sequence, with some being expressed at high levels early in development but then diminishing, others increasing continuously over the first 2 weeks of postnatal life to achieve adult levels, and still others showing a rise and fall over a relatively brief period. Results of preliminary studies using a monospecific antibody to the previously identified growth-associated protein, GAP-43, parallel the results of our metabolic labeling studies and show striking developmental changes in both the level and localization of this protein in the primary visual system.

\section{Materials and Methods}

Labeling of proteins rapidly transported to the SC. Syrian hamsters (Mesocricetus auratus) were bred in our colony. The specific ages used in this study were selected because of their correspondence with major 

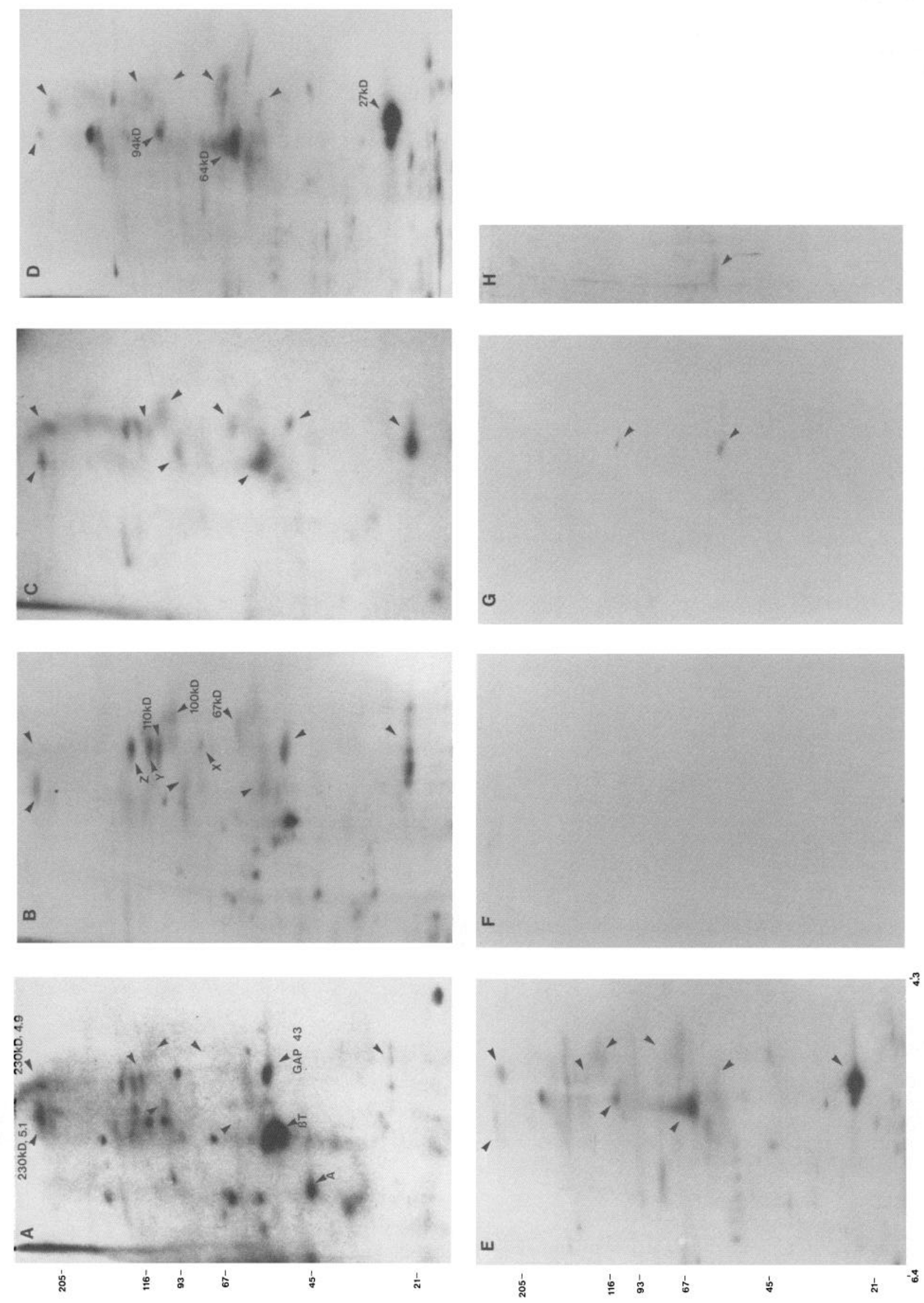
Table 1. Quantitation of rapidly transported proteins

\begin{tabular}{|c|c|c|c|c|c|c|c|c|c|}
\hline & \multicolumn{3}{|l|}{ P2 } & \multicolumn{3}{|l|}{ P5 } & \multicolumn{3}{|l|}{ Adult } \\
\hline & $\begin{array}{l}\text { Contra } \\
(\mathrm{cpm})\end{array}$ & $\begin{array}{l}\text { Ipsi } \\
\text { (cpm) }\end{array}$ & $\begin{array}{l}\% \text { of } \\
\text { transport }\end{array}$ & $\begin{array}{l}\text { Contra } \\
\text { (cpm) }\end{array}$ & $\begin{array}{l}\text { Ipsi } \\
\text { (cpm) }\end{array}$ & $\begin{array}{l}\% \text { of } \\
\text { transport }\end{array}$ & $\begin{array}{l}\text { Contra } \\
\text { (cpm) }\end{array}$ & $\begin{array}{l}\text { Ipsi } \\
\text { (cpm) }\end{array}$ & $\begin{array}{l}\% \text { of } \\
\text { transport }\end{array}$ \\
\hline GAP-43 & 240.6 & 82.9 & 10.3 & 131.2 & 34.0 & 13.6 & 37.8 & - & 2.4 \\
\hline $230 \mathrm{kDa} \mathrm{b}$ & 280.4 & 96.9 & 12.0 & 60.2 & 0.0 & 8.4 & 3.9 & - & 0.2 \\
\hline $230 \mathrm{kDa} a$ & 605.4 & 0.0 & 39.5 & 66.8 & 0.0 & 9.3 & 27.5 & - & 1.7 \\
\hline $27 \mathrm{kDa}$ & 199.5 & 41.4 & 10.3 & 214.6 & 16.8 & 27.7 & 889.2 & - & 55.4 \\
\hline $64 \mathrm{kDa}$ & 0.0 & 0.0 & 0.0 & 0.0 & 0.0 & 0.0 & 358.1 & - & 22.3 \\
\hline $94 \mathrm{kDa}$ & 88.0 & 68.3 & 1.3 & 0.0 & 0.0 & 0.0 & 85.9 & - & 5.4 \\
\hline $100 \mathrm{kDa}$ & 85.0 & 35.4 & 3.2 & 55.6 & 0.0 & 7.8 & 29.3 & - & 1.8 \\
\hline $110 \mathrm{kDa}$ & 133.7 & 69.8 & 4.2 & 65.2 & 8.4 & 7.9 & 34.0 & - & 2.1 \\
\hline $67 \mathrm{kDa}$ & 0.0 & 0.0 & 0.0 & 43.2 & 0.0 & 6.0 & 53.4 & - & 3.3 \\
\hline $\mathrm{X}$ & 73.3 & 52.1 & 1.4 & 21.8 & 3.4 & 2.6 & 0.0 & - & 0.0 \\
\hline $\mathrm{Y}$ & 174.0 & 77.7 & 6.3 & 67.8 & 8.4 & 8.3 & 45.0 & - & 2.8 \\
\hline $\mathrm{Z}$ & 261.0 & 82.0 & 11.7 & 62.4 & 2.8 & 8.3 & 38.4 & - & 2.4 \\
\hline Total & 1534.4 & & & 715.0 & & & 1602.5 & & \\
\hline
\end{tabular}

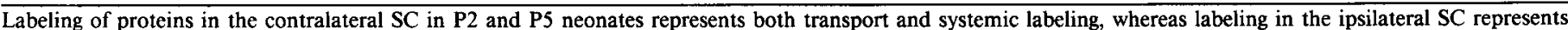

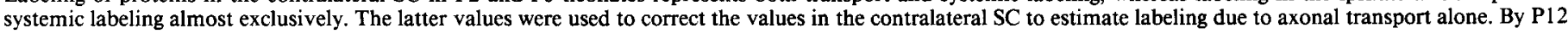
virtually no systemic labeling occurs.

events in optic tract development (see Fig. 2J). Neonates (P2 and P5, where $\mathrm{P} 0=$ day of birth) were anesthetized by hypothermia and injected in one eye with $100 \mu \mathrm{Ci}{ }^{35} \mathrm{~S}$-methionine $(1000 \mathrm{Ci} / \mathrm{mmol}$, New England Nuclear, Boston; or Tran ${ }^{35} \mathrm{~S}-$ label, $1100 \mathrm{Ci} / \mathrm{mmol}, \mathrm{ICN}$, Irvine, CA) in $1 \mu 10.05 \mathrm{M}$ PBS, pH 7.4. Earlier results have shown that in neonates the high degree of nonspecific background labeling due to the immaturity of the blood-brain barrier can be minimized by giving large systemic injections of nonradioactive amino acid to compete with labeled precursor that diffuses out of the eye and into the circulation (Moya et al., 1987a). Animals at P2, P5, and P12 were therefore injected intraperitoneally with nonradioactive leucine (Sigma, $1 \mathrm{mg} / \mathrm{gm}$ body wt) dissolved in PBS, administered at the same time as the intraocular injection. Labeling in P12, P17, and adult animals was achieved by anesthetizing hamsters with Chloropent $(0.35 \mathrm{mg} / 100 \mathrm{gm}$ body wt, Fort Dodge Laboratories) and injecting $100 \mu \mathrm{Ci}$ of ${ }^{3 s} \mathrm{~S}$-methionine dissolved in $2 \mu \mathrm{l}$ PBS into the eye. All animals recovered under a heat lamp. After allowing $4 \mathrm{hr}$ for the labeled methionine to be incorporated into newly synthesized proteins within retinal ganglion cells and rapidly transported to central targets, the ipsilateral and contralateral superior colliculi (SC) were rapidly dissected out, frozen on dry ice, and stored separately at $-70^{\circ} \mathrm{C}$.

Tissues from 4-6 animals per age group were pooled and homogenized in ice-cold sucrose buffer [0.32 M sucrose (Schwarz-Mann, Cambridge, MA), $50 \mathrm{~mm}$ Tris-HCl, pH 7.4, $10 \mathrm{~nm}$ RNase, and $10 \mathrm{~nm}$ DNase (Sigma)] and then centrifuged at $100,000 \times g$ for $60 \mathrm{~min}$ at $4^{\circ} \mathrm{C}$ to yield a total particulate fraction. This was lyophilized to remove water, then solubilized in isoelectric focusing buffer [O'Farrell, 1975; $1 \mu \mathrm{g}$ of protein $/ \mu$ ] of $9.5 \mathrm{M}$ urea (Schwarz-Mann), 5\% $\beta$-mercaptoethanol (BioRad), 6\% ampholines in a ratio of $2: 2: 1$ of pH 3.5-5.0, pH 5.0-8.0, pH 3.5-10.0 (LKB, Gaithersburg, MD), 2\% NP-40 (Nonidet, Particle Data Labo- ratories, Elmhurst, IL)] for $30 \mathrm{~min}$ at $30^{\circ} \mathrm{C}$. Between 200 and $400 \mu \mathrm{g}$ of total protein was subjected to isoelectric focusing ( $16 \mathrm{hr}$ at $300 \mathrm{~V}, 4 \mathrm{hr}$ at $400 \mathrm{~V})$. After completion of the run, gels were equilibrated in SDSgel buffer (pH 6.8: Solution "O"; O'Farrell, 1975) for at least $30 \mathrm{~min}$ at room temperature and the proteins separated in the second dimension by SDS-PAGE on a 5-15\% linear acrylamide gradient. Gels were fixed with acetic acid/methanol, stained with Coomassie brilliant blue (Sigma), impregnated with a radiographic enhancer, Autofluor (National Diagnostics, Somerville, NJ), dried under vacuum onto filter paper (Whatman No. 1), and exposed to presensitized X-ray film (Kodak, X-Omat AR) for times ranging from 40 to $60 \mathrm{~d}$. Gel electrophoresis of tissue from each age group was replicated in 6 separate experiments. Three 2-dimensional gels from each age group were quantitatively analyzed as described below.

Quantitation of rapidly transported proteins. A tracing of each fluorogram was prepared on acetate sheets and used as a template to cut labeled proteins from the gels. Excised gel pieces were solubilized in $6 \%$ Protosol in Econofluor (New England Nuclear/Dupont) and the amount of radioactivity determined by liquid scintillation counting. In the P2 and P5 nconates, some systemic background labeling could still be detected on the fluorograms, as indicated by the presence of certain labeled proteins known not to be conveyed in the rapid phase of axonal transport (e.g., actin and tubulin: see Fig. $1 A$ ) in both the ipsi- and contralateral colliculi. The ipsilateral $\mathrm{SC}$, which receives only a relatively minor retinal projection in the hamster, shows a labeling pattern that predominantly reflects systemic labeling due to diffusion of ${ }^{35} \mathrm{~S}$-methionine out of the eye (Moya et al., 1987a). In order to eliminate the contribution of locally synthesized proteins from the quantitation of transported proteins, the radioactivity for each protein observed in the ipsilateral SC (i.e., background) was subtracted from that in the con-

Figure 1. Rapidly transported proteins in the developing hamster retinofugal pathway. Proteins were labeled by intraocular injection of ${ }^{35} S-$ methionine; after allowing $4 \mathrm{hr}$ for proteins synthesized in retinal ganglion cells and conveyed by rapid axonal transport to accumulate in the nerve endings, particulate proteins in the SC were analyzed by 2-dimensional gel electrophoresis and fluorography. Fluorograms are shown with apparent molecular weight in kilodaltons along the ordinate and isoelectric point (pI) along the abscissa. In the P2 and P5 neonates $(A$ and $B$ ) several proteins not conveyed in rapid axonal transport were systemically labeled due to the immaturity of the blood-brain barrier (e.g., actin, $A$; and $\beta$-tubulin, $\beta T$ ). Other proteins that show marked developmentally regulated changes are indicated with arrows. $A, \mathrm{P} 2 ; B, \mathrm{P} 5 ; C, \mathrm{P} 12 ; D, \mathrm{P} 17 ;$ and $E$, adult. $F-H$, Two-dimensional Western blot of total particulate brain proteins from neonatal hamsters reacted with an antiserum to GAP-43. Proteins were separated by 2-dimensional gel electrophoresis under nonreducing conditions $(F$ and $G)$ or reducing conditions $(H)$ and then transferred electrophoretically to a nitrocellulose membrane. The resulting blots of proteins separated under nonreducing conditions were reacted with preimmune serum $(F)$ or with an antiserum made against the GAP-43 protein of rat, which recognized hamster brain proteins (arrowheads, $G$ ) with the identical $\mathrm{p} I$ to GAP-43 (4.8) and apparent molecular weights of 50 and $100 \mathrm{kDa}$. When the blot of proteins separated under normal reducing conditions was reacted with the anti-GAP-43 antiserum, a single protein with apparent molecular weight $50 \mathrm{kDa}$ and $\mathrm{p} I 4.8 \mathrm{was}$ visualized $(H)$. 

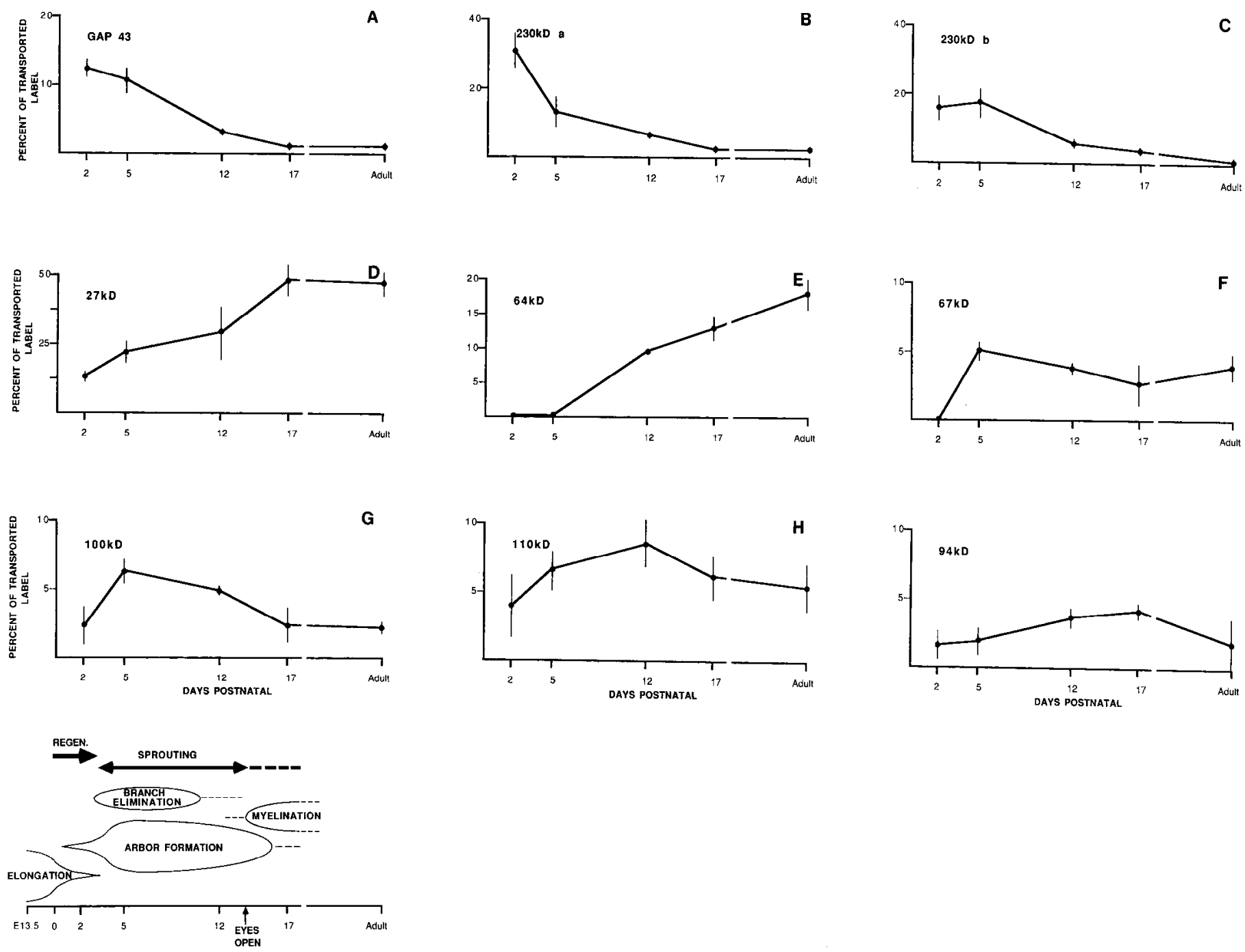

Figure 2. Quantitative analysis of rapidly transported proteins during development. Rapidly transported proteins were cut from the gels and radioactivity determined by liquid scintillation counting. The radioactivity for each protein is expressed as a percentage of the total rapidly transported radioactivity at each age. Each data point is the mean $( \pm$ SEM) from 3 different experiments. In some cases the error bars are less than the size of the symbol (๑). Top row, Proteins that decline in synthesis and transport during development include $(A) \mathrm{GAP}-43$ and two $(B$ and $C) 230 \mathrm{kDa}$ proteins, $\mathrm{p} I 4.9$ and 5.0. Upper middle row, Proteins that increase during development and remain high include proteins with apparent molecular weights $(\mathrm{kDa})$ of $(D) 27,(E) 64$, and $(F)$ 67. Lower middle row. Proteins that initially increase in synthesis and transport and subsequently decrease include $(G-I)$ the 100,110 , and $94 \mathrm{kDa}$ proteins. Bottom, Schematic representation showing the time course of morphological changes in the developing retinofugal pathway.

tralateral SC. The adjusted radioactivity for each protein was then normalized to the total radioactivity in transported proteins on each fluorogram. This normalization allowed us to express the labeling of each protein as a fraction of total rapidly transported protein and also helped to minimize the effects of possible age-dependent differences in protein synthesis in the retina, rate of axonal transport, or number of labeled proteins transported.

Immunohistochemical localization of GAP-43 in the developing visual system. The preparation of the immune serum used to visualize one identified growth-associated protein, GAP-43, has been described previously (Neve et al., 1987; Benowitz et al., 1988). To test this immune serum for cross-reactivity and specificity for hamster GAP-43, $400 \mu \mathrm{g}$ of particulate brain protein from neonatal hamsters was prepared by subcellular fractionation and subjected to 2-dimensional gel electrophoresis as described above. In other experiments, separation on SDSslab gels was done under nonreducing conditions (i.e., without $\beta$-mercaptoethanol in the SDS-gel buffer: buffer "O"; $O$ 'Farrell, 1975) in order to minimize a staining artifact in the Western blots (see below). Proteins were transferred clectrophoretically to nitrocellulose as described by Phelps (1984), with the modifications of Meiri et al. (1986), and the resulting blot was reacted with the antibody to GAP-43 at a dilution of
1:1000. Immunoreactivity was visualized using a peroxidase-conjugated secondary antibody. To enhance the contrast of the reaction product, a double-chromogen method was used in which peroxidase was visualized with $0.05 \%$ 4-chloro-napthol in $20 \%$ methanol and $0.05 \% \mathrm{H}_{2} \mathrm{O}_{2}$ in Trisbuffered saline (TBS), followed by $0.05 \%$ diamino benzidine (DAB) in TBS with $0.01 \% \mathrm{H}_{2} \mathrm{O}_{2}$.

For immunohistochemistry, $\mathrm{P} 2$ and adult hamsters were deeply anesthetized with Chloropent and perfused transcardially with a brief saline rinse, followed by $4 \%$ paraformaldehyde in $0.1 \mathrm{M}$ PBS. Brains were removed, postfixed for $2 \mathrm{hr}$ at $4^{\circ} \mathrm{C}$, and then cryoprotected in buffered sucrose. Frozen $40 \mu \mathrm{m}$ sections were cut in the transverse plane on a sliding microtome. Sections were placed in $0.3 \% \mathrm{H}_{2} \mathrm{O}_{2}$ in methanol for 30 min to neutralize endogenous peroxidases, washed in PBS containing $0.4 \%$ Triton X-100 (Sigma) and $0.5 \% \mathrm{NaNH}_{3}$ (PBSTN) and incubated in a blocking solution (PBSTN with 20\% normal rabbit serum) for 30 $\mathrm{min}$. Sections were then incubated for $3 \mathrm{~d}$ with the primary antibody or with nonimmune serum as a control, at a dilution of 1:2000, washed in PBSTN, incubated for $1 \mathrm{hr}$ with biotinylated rabbit anti-sheep IgG (Vector Labs), washed again in PBSTN, and incubated for $1 \mathrm{hr}$ with avidin-biotin conjugated to HRP prepared according to the manufacturer's directions (Vector Labs). Tissue was washed once in PBSTN 
followed by 2 washes in TBS. Peroxidase was visualized histochemically using DAB as the chromogen. Sections were mounted onto alum-gelatincoated slides, air-dried, and covered.

\section{Results}

\section{Labeled proteins rapidly transported to the $S C$}

The pattern of proteins synthesized in the retina and rapidly transported to central targets was found to change markedly during development (Fig. 1, $A-E$ ). Table 1 presents quantitative data for 3 representative ages and shows the degree of systemic labeling in the P2 and P5 neonates. By P12, systemic labeling became insignificant, diminishing to less than $0.3 \%$ of the total label incorporated into the SC (data not shown).

Prominent among the proteins transported to the $\mathrm{SC}$ in $\mathrm{P} 2$ and P5 neonates was one with an apparent molecular weight of $50 \mathrm{kDa}$ and $\mathrm{p} I$ of 4.8 (Fig. $1, A, B$ ). This protein is similar in its electrophoretic mobility, shape, and presence in the rapid phase of transport to the identified growth-associated protein, GAP-43 (Skene and Willard, 1981a, b; Jacobson et al., 1986; Meiri et al., 1986; Moya et al., 1987a). The results of the 2-dimensional Western blot reacted with an immune serum generated against GAP-43 from rat show that the $50 \mathrm{kDa}, \mathrm{p} l$ 4.8 protein in hamster is immunologically similar to the rat protein (see below) and hence is referred to hereafter as GAP43. By P12 labeling of this protcin had dcclincd and was nearly undetectable in the $\mathrm{P} 17$ and adult SC (Fig. 1, $C-E$ ). Quantitative analysis showed that GAP-43 accounted for 12.5 and $10.8 \%$ of the total radioactivity transported to the SC at P2 and P5, respectively; at $\mathrm{P} 12$, it was about one-third this level, while at $\mathrm{P} 17$ and in the adult, it was about $1 \%$ (Fig. $2 A$ ).

Two high-molecular-weight proteins of about $230 \mathrm{kDa}, \mathrm{p} / 4.9$ and 5.1, also showed a striking decline during development. The more acidic of these (Fig. $1 \mathrm{~A}$ ), contained over $30 \%$ of the label in rapidly transported proteins at $\mathrm{P} 2$, decreased to less than $13 \%$ at P5, and to about $2 \%$ in the adult (Fig. 2C). The more basic protein declined somewhat more gradually, going from about $17 \%$ at P2 and P5, to a third of this level at P12, and then diminishing further (Fig. $2 B$ ). By contrast, proteins $Y$ and $\mathrm{Z}$ (Fig. $1 B$ ) showed only a minimal decline with increasing age (Table 1).

A $27 \mathrm{kDa}, \mathrm{p} I 4.8$ protein showed a complementary time course of expression (Fig. 1, $A-E$ ). Its synthesis and transport increased steadily throughout the first 3 weeks of postnatal life and remained high in the adult. Quantitative analysis showed that at $\mathrm{P} 2$, the $27 \mathrm{kDa}$ protein accounted for $13.4 \%$ of the total label in rapidly transported components in SC, whereas by $\mathrm{P} 17$ it was about $50 \%$ (Fig. $2 D$ ). Two proteins with molecular weights of $64 \mathrm{kDa}, \mathrm{p} I 5.5$, and $67 \mathrm{kDa}, \mathrm{p} I 4.7$, also increased sharply but with a delayed onset. The $67 \mathrm{kDa}$ protein was not observed on $\mathrm{P} 2$ but increased abruptly at P5. The $64 \mathrm{kDa}$ protein could not be detected at $\mathrm{P} 2$ and $\mathrm{P} 5$, but by $\mathrm{P} 12$ (Fig. $1, C-E$ ) this protein comprised about $10 \%$ of the total labeling and about $20 \%$ in the adult (Fig. 2E).

Proteins with apparent molecular weights of about 100 and $110 \mathrm{kDa}$ showed a distinctive pattern of expression, increasing rapidly and then decreasing again during later stages (Fig. 1, $A-$ $E$ ). Labeling of these 2 proteins was low in the SC on P2, increased by $\mathrm{P} 5$, and then declined after P12. Another protein, $94 \mathrm{kDa}$, showed a more gradual rise and fall, as did the protein labeled $\mathrm{X}$ in Figure $1 B$. In general, the mature pattern of protein labeling appears to be achieved by P17.
Immunohistochemical localization of GAP-43 in the developing visual system

The sheep antiserum raised against rat GAP-43 reacted specifically with the apparently homologous protein on a 2-dimensional gel Western blot containing all hamster brain particulate proteins (Fig. 1, $G, H$ ). Under nonreducing conditions, 2 spots with identical isoelectric points and apparent molecular weights of 50 and $100 \mathrm{kDa}$ were visualized (Fig. $1 G$ ). However, in the presence of $\beta$-mercaptoethanol, only a single spot of $50 \mathrm{kDa}, \mathrm{p} I$ 4.8, was seen (Fig. $1 H$ ). The $100 \mathrm{kDa}, \mathrm{p} / 4.8$, species recognized by the antibody to GAP-43 in the nonreducing conditions is likely to be a polymeric form of GAP-43, as suggested by results from size-exclusion chromatography experiments (Benowitz et al., 1987).

Use of this antibody in immunohistochemical studies revealed marked differences in the abundance and distribution of GAP-43 between neonatal and adult brain tissue. In general, the neonatal brain sections were more darkly stained than the adult (Fig. 3, $B, C, E$ ). This staining was specific for the antigen, since sections reacted with nonimmune serum exhibited virtually no staining (Fig. $3 A$ ). Moreover, marked regional variations in staining patterns were observed in both the neonate and the adult. In the immature brain, considerable amounts of GAP43 were detected along axon bundles, whereas in more mature tissue, immunoreactivity was restricted to specific central nuclear groups and was virtually absent in most fiber tracts.

The optic tract was densely stained in the retinofugal system of $\mathrm{P} 2$ neonates, as were fiber fascicles within the dorsal nucleus of the lateral geniculate body (LGBd) and axons in the brachium of the SC (Fig. $3 E$ ). In the $\mathrm{SC}$, positively stained fiber bundles were observed coursing longitudinally throughout the superficial layers in a distribution similar to that of fascicles of retinal axons at this age (Fig. 3, B, C). In contrast to this neonatal pattern, the optic tract of adult hamsters was virtually devoid of staining, while the neuropil of the lateral geniculate and the $\mathrm{SC}$ were only lightly stained (Fig. 3, $D, F$ ). The detailed time course of immunohistochemical staining for GAP-43 is currently bcing investigated (see Moya et al., 1987b).

\section{Discussion}

During development, proteins conveyed to nerve terminal membranes in the rapid phase of axonal transport are likely to contribute to processes that underlie axon elongation and the establishment of functional synapses, including growth cone motility, target recognition, membrane turnover, cell-cell adhesion, control of specific ion fluxes, and the development of synaptic specializations. The results of the present study demonstrate striking changes in the synthesis of many of these proteins over time, some of which appear to be temporally correlated with specific changes in the development of the retinofugal projection.

\section{Technical considerations}

Variability between fluorograms, due to differences in amount of radioactivity and in the exposure of the photographic emulsion, limits the interpretations of qualitative comparisons to the most obvious changes in labeling patterns. To overcome this limitation, we have quantified the radioactivity in each rapidly transported protein, eliminated background labeling, and used a normalization procedure to allow comparisons to be made over different ages. Background labeling was eliminated by sub- 

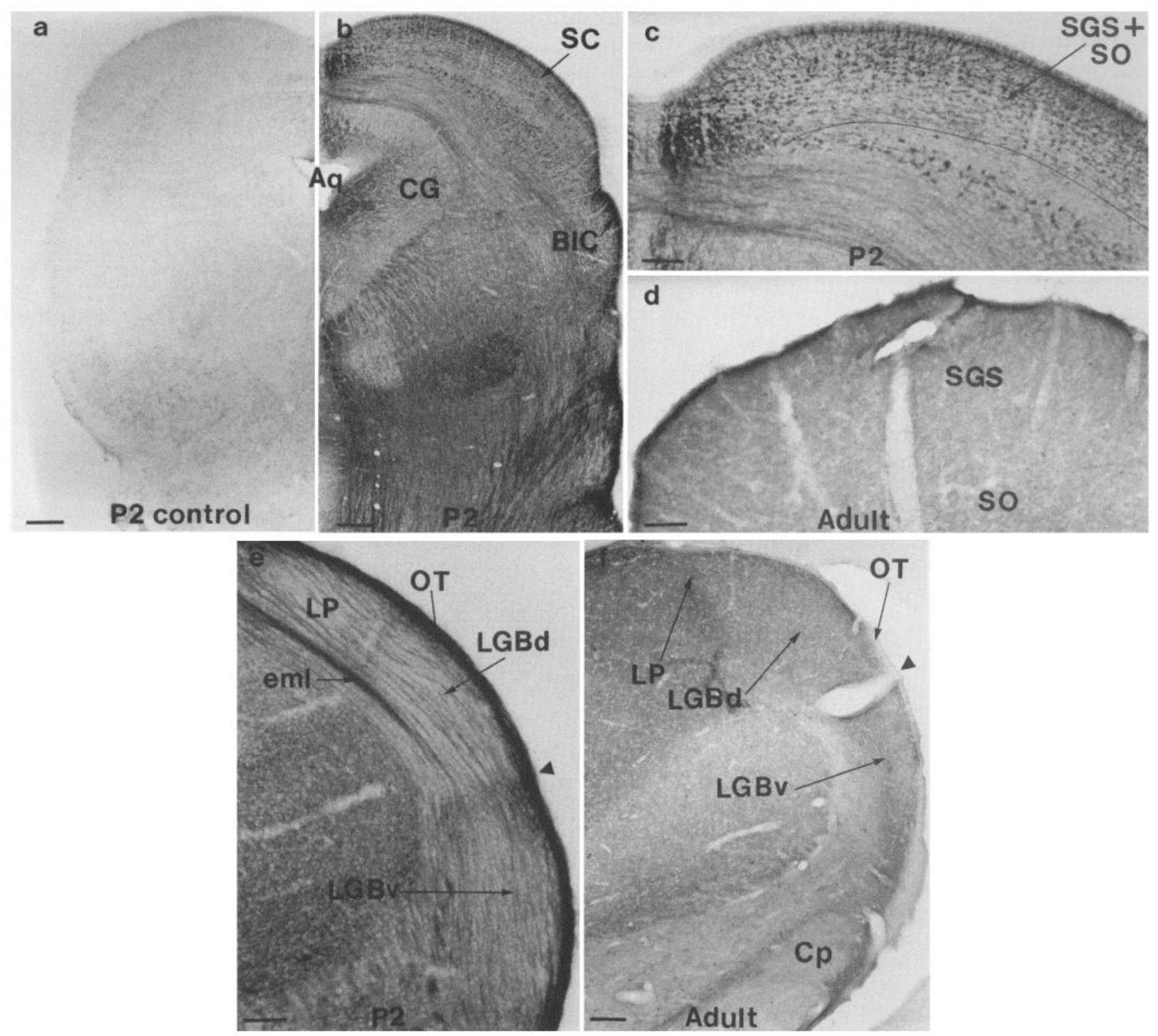

Figure 3. Immunohistochemical localization of GAP-43 in transverse sections through $\mathrm{P} 2(a-c$ and $e$ ) and adult $(d$ and $f)$ hamster brain. $a$, Control section through midbrain of P2 animal incubated with nonimmune serum. $b$, Midbrain section reacted with monospecific antibody to GAP-43. Note intense staining of axon bundles and fiber tracts. $c$, Higher-power view of superior colliculus from $b$. Thin black line delineates ventral border of the retinal-recipient zone (SGS+SO). Staining is restricted to axon bundles in the medial and superficial regions of this zone. $d$, Similar section through SGS and SO of an adult brain. Only light staining in neuropil is evident. $e$ and $f$, Staining pattern seen in lateral thalamus of P2 and adult animals. Note positive staining in axons of the optic tract and eml in neonates, whereas retinal axons in mature animals are devoid of reaction product. Abbreviations: $A q$, aqueduct of Sylvius; $B I C$, brachium of the inferior colliculus; $C G$, central gray; $C P$, cerebral peduncle; $e m l$, external medullary lamina; $L G B d$ and $L G B v$, dorsal and ventral nuclei of the lateral geniculate body; $L P$, lateral posterior thalamic nucleus; $O T$, optic tract; $S C$, superior colliculus; $S G S$, superficial gray layer; $S O$, optic fiber layer. Scale bar, $100 \mu \mathrm{m}$ in $a, b$, and $f ; 200 \mu \mathrm{m} c-e$.

tracting the counts for each protein in the ipsilateral SC from those in the contralateral SC, assuming that the ipsilateral pattern is primarily a reflection of systemic labeling (see Table 1). The existence of a minor ipsilateral retinotectal projection results in a slight underestimation of the levels of contralaterally transported protein using this method. However, the ipsilateral retinotectal projection in adult hamsters derives from only 1.2$1.7 \%$ of all retinal ganglion cells (Hsiao et al., 1984). While this projection is somewhat larger in the neonates, estimates derived from other rodent species suggest that in P2 and P5 animals, the subtraction procedure would decrease actual values by less than $6 \%$ and probably would not affect normalized values at all.

The normalization of background-corrected radioactivity for each protein to the total rapidly transported radioactivity was done in order to take into consideration possible developmental changes in rates of protein synthesis and axonal transport and in the number of transported proteins. Such developmental changes made it impossible to identify a single unchanging, labeled protein to use as a reference. However, as a result of 
applying this normalization procedure, we cannot rule out the possibility, for example, that reported changes in the level of a protein could result from a second molecular species dominating the labeling pattern at a particular age rather than the level of the first protein actually decreasing. While a comparison of absolute levels of specific proteins would be interesting, this is technically difficult, and our data should be viewed as showing changes in the expression of each protein relative to the entire pattern of rapidly transported proteins during development. The reliability of this method is confirmed by the multiple replications for each age and by additional quantitative data on the pattern of rapidly transported proteins in the lateral geniculate body of these same cases, which is entirely consistent with the present results (unpublished data). For one particular protein, GAP-43, the validity of our results is also underscored by the high correlation between the quantitative analysis and the immunohistochemical data on this protein (see also Moya et al., 1987b). Finally, it should be noted that the data were derived with the usc of a singlc amino acid to label proteins. Use of another amino acid (e.g., proline) would undoubtedly change the relative levels of labeling in various proteins with respect to one another but would not be expected to affect significantly the temporal pattern of change for a particular protein during development.

\section{Development of the hamster retinofugal pathway}

Anatomical studies in the hamster have provided considerable data on the major developmental events in the primary visual pathway (Frost et al., 1979; Jhaveri et al., 1983; Sachs and Schneider, 1984; Schneider et al., 1985; cf. Sachs et al., 1986, for a comparison of development in the mouse). In the hamster, the first retinal axons leave the eye at embryonic day 11.5 (E11.5; day of mating $=E 0$ ) and elongate rapidly, growing at a rate of $60-100 \mu \mathrm{m} / \mathrm{hr}$ over the surface of the lateral geniculate and reaching the caudal end of the SC by E13.5. At these early stages, retinofugal axons have a simple morphology with numerous varicosities and short filopodial extensions. Around the time of birth (E15.5), collateral branches from these axons begin to penetrate target zones. By P5, a single terminal arbor is being elaborated on each axon in the SC, as extraneous branches are being eliminated. Also by $\mathrm{P} 5$, an adultlike precision in retinotectal topography is nearly established. During the next 2 weeks arbors elaborate extensively and increasing numbers of synapses develop with target cells in the brain. Eye opening occurs on P14. Myelination of optic tract axons begins around the same time and is accompanied by a dramatic increase in the diameter of the axons.

Paralleling the normal progression of developmental changes is a progressive decline in the plasticity of the optic axons in response to injury. Prior to the time of retinotectal arbor formation, transection of the optic tract just anterior to the SC results in retinal axon regeneration, whereas axons cut after P3 fail to regrow across the region of transection (So et al., 1981). On the other hand, the critical period for collateral sprouting of retinal arbors into nearby vacated terminal space persists for at least 2 weeks after birth (Schneider et al., 1985).

The timing of these anatomical phenomena is summarized in Figure $2 J$. The temporal changes in the expression of certain molecular species appear to be correlated with major events of axonal growth (compare Figs. $2 A-I$ and $2 J$ ). For example, the time at which retinal axons cease fasciculated elongation and begin to arborize in target areas (i.e., between P2 and P5) co- incides with the decline in synthesis and transport of the 230 $\mathrm{kDa}$ proteins and the relative increase in the 67 and $110 \mathrm{kDa}$ proteins. This transition also coincides with the loss in the ability of retinal axons to regenerate across a transection of the tract. During the early period of active terminal arbor elaboration (P5), 2 proteins that were low in the $\mathrm{P} 2$ neonate (e.g., 100 and $110 \mathrm{kDa}$ ) reach high levels; both proteins subsequently decline at the time when the adult morphology is achieved. As retinal axons arborize extensively in the SC from P5 to P12, the 50 $\mathrm{kDa}$ (GAP-43) and the basic $230 \mathrm{kDa}$ protein diminish greatly. Between P12 and P17, when retinal axons have eliminated extraneous collateral branches and more mature terminal arbors are formed, the transport of the 27 and $64 \mathrm{kDa}$ proteins essentially reaches mature levels. This period also coincides with the time at which retinal axons lose their ability to extend collateral branches into newly available target space.

\section{GAP-43 in the developing optic pathway}

One protein that shows a striking developmental regulation is identical to the growth-associated phosphoprotein, GAP-43, in terms of its apparent molecular weight, isoelectric point, developmental regulation, presence in the rapid phase of axonal transport, and immunological characteristics (Skene and Willard, 1981a, b; Jacobson et al., 1986). GAP-43 in rat is also similar to a protein described in regenerating goldfish optic nerve (48K 4.8, GAP-48 or protein 4: Benowitz and Lewis, 1983; Perrone-Bizzozero and Benowitz, 1987; Perry et al., 1987) and is identical to the membrane phosphoprotein described as pp46, B-50 or F1 (Zwiers et al., 1980; Katz et al., 1985; Nelson and Routtenberg, 1985; Jacobson et al., 1986; Meiri et al., 1986; Perrone-Bizzozero et al., 1986; Snipes et al., 1988). Convergent studies from several laboratories show that GAP-43 is a membrane-bound substrate of protein kinase $C$ that is enriched in growth cones and immature synapses (DeGraan et al., 1985; Katz et al., 1985; Meiri et al., 1986; Skene et al., 1986). In addition to its presence in the developing or regenerating optic pathway (Benowitz et al., 1981, 1983; Skene and Willard, 1981a, b; Freeman et al., 1986; also preliminary studies in the hamster visual system: Moya et al., 1987a, b), high levels of synthesis and transport of GAP-43 have been observed in other immature neuronal systems (Jacobson et al., 1986; Kalil and Skene, 1986), cultured embryonic CNS neurons (Perrone-Bizzozero et al., 1987), and pheochromocytoma cells undergoing NGF-induced differentiation (Van Hooff et al., 1986; Basi et al., 1987; Karns et al., 1987).

The present studies show that synthesis and transport of this protein are high in the hamster retinofugal pathway during early stages of arbor formation. Similarly, synthesis and transport of GAP-43 are highest in the hamster pyramidal tract (Kalil and Skene, 1986) at a time when corticospinal axons initiate collateral penetration into thalamic and pontine nuclei (Reh and Kalil, 1981, Fig. 8). In the developing rat cerebral cortex as a whole, overall levels are greatest during the first week after birth (Jacobson et al., 1986), a time at which most axons have initiated terminal arbor formation.

Use of a monospecific antibody also shows that at P2 high levels of GAP-43 are present in the known position of the retinal fibers in the optic tract, lateral geniculate nucleus, and SC. At this time, corticotectal axons have not yet invaded the SC (Ramirez et al., 1986), and hence the staining observed in the SC most likely represents the distribution of this protein along retinal fibers. Thus, high levels of GAP-43 in nerve terminals and 
along retinal axons are seen at the time at which the specific target is reached. While synthesis of GAP-43 relative to other rapidly transported proteins declines after $\mathrm{P} 5$, absolute amounts of the protein in nerve terminals may remain high throughout the period of elaboration of end arbors. In the regenerating goldfish optic pathway, the expression of this protein remains above baseline levels during the entire period in which activitydependent tuning of the retinotectal visual map occurs (Benowitz and Schmidt, 1987). Conceivably, the presence of GAP43, at least during the initial period of arborization in the developing hamster optic pathway, may likewise be permissive for activity-dependent tuning processes in this system.

While levels of GAP-43 become vanishingly low in the developing retinofugal pathway after the second postnatal week, the protein continues to be synthetized at high levels in certain other neurons (Neve et al., 1987) and is enriched in particular regions of the adult brain (see LP in Fig. $3 E$; Oestreicher and Gispen, 1986; Benowitz et al., 1988). In addition, changes in this protein's phosphorylation are highly correlated with longterm potentiation in rat hippocampus (Nelson and Routtenberg, 1986; Lovinger et al., 1985). Thus, it is possible that in those neural systems in which GAP-43 synthesis remains elevated into maturity, the protein may play an ongoing role in the modulation of synaptic function.

\section{Other protein changes}

Levels of the rapidly transported acidic $230 \mathrm{kDa}$ protein declined even earlier than GAP-43. The protein resembles the polysialated form of the neural cell adhesion molecule, N-CAM, in terms of its apparent molecular weight (200-250k), and $\mathrm{p} I$ (4.4-4.6; Hoffman et al., 1982). Should further studies demonstrate (e.g., by immunological or sequence criteria) that the $230 \mathrm{kDa}$ species is indeed a form of N-CAM, this would suggest that the synthesis or posttranslational modification of this molecule may be precisely timed to regulate adhesive interactions between cells during specific developmental events, e.g., the end of fasciculated axon elongation (see Schlosshauer et al., 1984).

Three other constituents of fast axonal transport were found to increase markedly during development. Two of these, the acidic 27 and $94 \mathrm{kDa}$ proteins, increased continuously after birth and reached mature levels by $\mathrm{P} 17$. The $27 \mathrm{kDa}$ protein appears to be identical to a protein described as S1, which, in damaged peripheral nerve, decreases sharply in synthesis and transport after nerve damage but then returns to high levels at about the time of synaptic contact (Redshaw and Bisby, 1985). The 94 $\mathrm{kDa}$ protein, which shows a more gradual increase, may be homologous to protein S1 4 described by Shirao and Obata(1985), which shows a similar increase during maturation of the chick optic tectum. The developmental increase in the 27 and $94 \mathrm{kDa}$ proteins observed in the present study coincides with changes in retinal axon size and the extent of terminal maturation (see Fig. $2 J$ ). The third protein in this group, $64 \mathrm{kDa}$, showed an abrupt increase, being undetectable in the P2 and P5 neonates but achieving high levels by P12. Thus, maximal synthesis and transport of the $64 \mathrm{kDa}$ protein begin at a time when retinal axons are actively elaborating terminal arbors and remain high in the adult. A protein with a similar shape, apparent molecular weight, and $\mathrm{p} I$ to the $64 \mathrm{kDa}$ species is rapidly transported in the intact hypoglossal nerve of rat but diminishes markedly in peripheral nerves during axonal regeneration (see Redshaw and Bisby, 1984, Fig. 5). The 27, 64, and $94 \mathrm{kDa}$ proteins thus appear to be associated with later stages of neural development and may be components of presynaptic receptors, transmitter vesicles, membrane channels, or other synaptic specializations, or could serve to stabilize the membrane or induce myelination.

Two acidic proteins with apparent molecular weights of 100 and $110 \mathrm{kDa}$ were low in the neonate, increased to peak levels by P5, and then declined to low levels in the adult. Hence, although these proteins may be required for events such as target recognition, they appear to be less essential once stable connections have been established. In the goldfish retinotectal projection, several acidic proteins of similar apparent molecular weights showed increased levels in synthesis and transport only during the time of initial contact with the appropriate target (Benowitz et al., 1983). Experimental verification of such target regulation in the hamster retinotectal projection is also possible by surgical manipulation that deprives axons of their appropriate targets (see Schneider, 1973; So and Schneider, 1978). Studies combining metabolic labeling with such manipulations may further show whether the macromolecular regenerative response to injury is a complete reinduction of the protein synthesis and transport patterns seen in the immature developing animal or whether the regenerative response reflects a distinct growth state.

It is interesting to note that in the present studies, essentially every protein conveyed to the nerve terminal membranes in the rapid phase of axonal transport underwent a marked change during development so that between P2 and P17 the labeling profile changed almost completely. Thus, in addition to the identity and physiological significance of the individual proteins visualized here, another question of interest concerns the nature of the signals that orchestrate this complex pattern of metabolic changes. In particular, it will be important to identify interactive events in which the pattern of molecular changes determines the morphological sequence of development and those in which dynamically changing interactions with extrinsic constituents induce the molecular changes observed. Recent reports have made it clear that the neuronal as well as the glial and end-organ environments can significantly alter the growth characteristics (Lance-Jones and Landmesser, 1981; So and Aguayo, 1985; Hantaz-Ambroise et al., 1987; Liuzzi and Lasek, 1987) and underlying pattern of gene expression in neurons (Benowitz et al., 1983; Redshaw and Bisby, 1985; Yoon et al., 1986; Baizer and Fishman, 1987).

\section{References}

Baizer, L., and M. C. Fishman (1987) Recognition of specific targets by cultured dorsal root ganglion neurons. J. Neurosci. 7: 2305-2311.

Basi, G. S., R. D. Jacobson, I. Virag, J. Schilling, and J. H. P. Skene (1987) Primary structure and transcriptional regulation of GAP-43, a protein associated with nerve growth. Cell 49: 785-791.

Benowitz, L. I., and E. R. Lewis (1983) Increased transport of 44,000to 49,000 -Dalton acidic proteins during regeneration of the goldfish optic nerve: A two-dimensional gel analysis. J. Neurosci. 3: 21532163.

Benowitz, L. I., and J. T. Schmidt (1987) Activity-dependent sharpening of the regenerating retinotectal projection in goldfish: Relationship to the expression of growth-associated proteins. Brain Res. 417: $118-126$.

Benowitz, L. I., V. E. Shashoua, and M. G. Yoon (1981) Specific changes in rapidly transported proteins during regeneration of the goldfish optic nerve. J. Neurosci. 1: 300-307.

Benowitz, L. I., M. G. Yoon, and E. R. Lewis (1983) Transported proteins in the regenerating optic nerve: Regulation by interactions with the optic tectum. Science 222: 185-188.

Benowitz, L. I., N. I. Perrone-Bizzozero, and S. P. Finklestein (1987) Molecular properties of the growth-associated protein GAP-43 (B50). J. Neurochem. 48: 1640-1647. 
Benowitz, L. I., P. J. Apostolides, N. Perrone-Bizzozero, S. P. Finklestein, and H. Zwiers (1988) Anatomical distribution of the growthassociated protein GAP-43/B-50 in the adult rat brain. J. Neurosci. 8: 339-352.

De Graan, P. N. E., C. O. M. Van Hooff, B. C. Tilly, A. B. Oestreicher, P. Schotman, and W. H. Gispen (1985) Phosphoprotein B-50 in nerve growth cones from fetal rat brain. Neurosci. Lett. 61: 235-241.

Freeman, J. A., S. Bock, M. Deaton, B. McGuire, J. J. Norden, and G. J. Snipes (1986) Axonal and glial proteins associated with development and response to injury in the rat and goldfish optic nerve. Exp. Brain Res. Suppl. 13: 34-47.

Frost, D., K.-F. So, and G. E. Schneider (1979) Postnatal development of retinal projections in Syrian hamsters with early lesions: A study using autoradiographic and anterograde degeneration techniques. Neuroscience 4: 1649-1677.

Grafstein, B., and D. S. Forman (1980) Intracellular transport in neurons. Physiol. Rev. 60: 1167-1283.

Hammerschlag, R., and G. C. Stone (1982) Membrane delivery by fast axonal transport. Trends Neurosci. 5: 12.

Hantaz-Ambroise, D., M. Vigny, and J. Koenig (1987) Heparan sulfate proteoglycan and laminin mediate two different types of neurite outgrowth. J. Neurosci. 7: 2293-2304.

Hoffman, S., B. C. Sorkin, P. C. White, R. Brackenbury, R. Mailhammer, U. Rutishauser, B. A. Cunningham, and G. M. Edelman (1982) Chemical characterization of a neural cell adhesion molecule purified from embryonic brain membranes. J. Biol. Chem. 257: 7720-7729.

Hsiao, K., G. M. Sachs, and G. E. Schneider (1984) A minute fraction of Syrian Golden hamster retinal ganglion cells project bilaterally. J. Neuroscience 4: 359-367.

Jacobson, R. D., I. Virag, and J. H. P. Skene (1986) A protein associated with axon growth, GAP-43, is widely distributed and developmentally regulated in rat CNS. J. Neurosci. 6: 1843-1855.

Jhaveri, S., M. Edwards, and G. E. Schneider (1983) Two stages of growth during development of the hamster's optic tract. Anat. Rec. 205: $225 \mathrm{~A}$.

Kalil, K., and J. H. P. Skene (1986) Elevated synthesis of an axonally transported protein correlated with axon outgrowth in normal and injured pyramidal tracts. J. Neurosci. 6: 2563-2570.

Karns, L. R., S.-C. Ng, J. Freeman, and M. C. Fishman (1987) Cloning of complementary DNA for GAP-43, a neuronal growth-related protein. Science 236: 597-600.

Katz, F., L. Ellis, and K. H. Pfenninger (1985) Nerve growth cones isolated from fetal rat brain. III. Calcium-dependent protein phosphorylation. J. Neurosci. 5: 1402-1411.

Lance-Jones, C., and L. Landmesser (1981) Pathway selection by embryonic chick motorneurons in an experimentally altered environment. Proc. R. Soc. London 214: 19-52.

Liuzzi, F. J., and R. J. Lasek (1987) Astrocytes block axonal regeneration in mammals by activating the physiological stop pathway. Science 237: 642-645.

Lorenz, T., and M. Willard (1978) Subcellular factionation of intraaxonally transported polypeptides in the rabbit visual system. Proc. Natl. Acad. Sci. USA 75: 505-509.

Lovingcr, D. M., R. F. Akcrs, R. B. Nelson, C. A. Barnes, B. L. McNaughton, and A. Routtenberg (1985) A selective increase in phosphorylation of protein $\mathrm{F} 1$, a protein kinase $\mathrm{C}$ substrate, directly related to three day growth of long term synaptic enhancement. Brain Res. 343: 137-143.

Meiri, K., K. H. Pfenninger, and M. Willard (1986) Growth-associated protein, GAP-43, a polypeptide that is induced when neurons extend axons is a component of growth cones and corresponds to pp 46 , a major polypeptide of a subcellular faction enriched in growth cones. Proc. Natl. Acad. Sci. USA 83: 3537-3541.

Moya, K. L., L. I. Benowitz, S. Jhaveri, and G. E. Schneider (1987a) Enhanced visualization of axonally transported proteins in the immature CNS by suppression of systemic labeling. Dev. Brain Res. 32: 183-191

Moya, K. L., S. Jhaveri, L. I. Benowitz, and G. E. Schneider (1987b) Immunohistochemical localization of a major growth-associated protein in the developing hamster visual system. Soc. Neurosci. Abstr. 13: 1479 .

Nelson, R. B., and A. Routtenberg (1985) Characterization of protein F1 (47kDa, $4.5 \mathrm{pl})$ : A kinase C substrate directly related to neural plasticity. Exp. Neurol. 89: 213-224.

Neve, R. L., N. I. Perrone-Bizzozero, S. Finklestein, H. Zwiers, E. Bird,
D. M. Kurnit, and L. I. Benowitz (1987) The neuronal growthassociated protein GAP-43 (B-50, F1): Neuronal specificity, developmental regulation and regional distribution of the human and rat mRNAs. Mol. Brain Res. 2: 177-183.

Oestreicher, A. P., and W. H. Gispen (1986) A radioimmunoassay (RIA) for the phosphoprotein B-50: Distribution in rat brain. J. Neurochem. 46: 1366-1369.

O'Farrell, P. H. (1975) High resolution two-dimensional electrophoresis of proteins. J. Biol. Chem. 250: 4007-4021.

Perrone-Bizzozero, N. I., and L. I. Benowitz (1987) Expression of a $48 \mathrm{kD}$ growh-associated protein in the goldfish retina. J. Neurochem. 48: 644-652.

Perrone-Bizzozero, N., S. P. Finklestein, and L. I. Benowitz (1986) Synthesis of a growth-associated protein by embryonic rat cerebrocortical neurons in vitro. J. Neurosci. 6: 3721-3730.

Perry, G., D. W. Burmeister, and B. Grafstein (1987) Fast axonally transported proteins in regenerating goldfish optic axons. J. Neurosci. 7: 792-806.

Phelps, D. S. (1984) Electrophoretic transfer of proteins from fixed and stained gels. Anal. Biochem. 141: 409-412.

Ramirez, J. J., J. Hahm, S. Jhaveri, and G. E. Schneider (1986) Development of the corticotectal projection in the Syrian hamster. Soc. Neurosci. Abstr. 12: 1374.

Redshaw, J. D., and M. A. Bisby (1984) Proteins of fast axonal transport in the regenerating hypoglossal nerve of the rat. Can. J. Physiol. Pharmacol. 62: 1387-1393.

Redshaw, J. D., and M. A. Bisby (1985) Comparison of the effects of sciatic nerve crush or resection on the proteins of fast axonal transport in rat dorsal root ganglion cell axons. Exp. Neurol. 88: 437-446.

Reh, T., and K. Kalil (1981) Development of the pyramidal tract in the hamster. 1. A light microscopic study. J. Comp. Neurol. 200: 5567.

Sachs, G., and G. E. Schneider (1984) The morphology of optic tract axons arborizing in the superior colliculus of the hamster. J. Comp. Neurol. 230: 155-167.

Sachs, G., J. Jacobsen, and V. S. Caviness, Jr. (1986) Postnatal changes in arborization patterns of murine retinocollicular axons. J. Comp. Neurol. 246: 395-408.

Schlosshauer, B., U. Schwarz, and U. Rutishauser (1984) Topological distribution of different forms of neural cell adhesion molecule in the developing chick visual system. Nature 310:141-143.

Schneider, G. E. (1973) Early lesions of superior colliculus: Factors affecting the formation of abnormal retinal projections. Brain Behav. Evol. 8: 73-109.

Schneider, G. E., S. Jhaveri, M. A. Edwards, and K.-F. So (1985) Regeneration, re-routing, and redistribution of axons after early lesions: Changes with age, and functional impact. In Recent Achievements in Restorative Neurology 1: Upper Motor Neuron Functions and Dysfunctions, J. C. Eccles and M. R. Dimitrijevic, eds., pp. 291-310, Karger, Basel.

Shirao, T., and K. Obata (1985) Two acidic proteins associated with brain development in chick embryo. J. Neurochem. 44: 1210-1216.

Skene, J. H. P., and M. Willard (1981a) Changes in axonally transported proteins during axon regeneration in toad ganglion cclls. $J$. Cell Biol. 89: 86-95.

Skene, J. H. P., and M. Willard (1981b) Axonally transported proteins associated with axon growth in rabbit central and peripheral nervous system. J. Cell Biol. 89: 96-103.

Skene, J. H. P., R. D. Jacobson, G. J. Snipes, C. B. McGuire, J. J. Norden, and J. A. Freeman (1986) A protein induced during nerve growth (GAP-43) is a major component of growth-cone membranes. Science 233: 783-786.

Snipes, G. J., C. B. McGuire, S. Chan, B. R. Costello, J. J. Norden, J. A. Freeman, and A. Routtenberg (1987) Evidence for the coidentification of GAP-43, a growth-associated protein, and F1, a plasticityassociated protein. J. Neurosci. 7: 4066-4075.

So, K.-F., and A. J. Aguayo (1985) Lengthy regrowth of cut axons from ganglion cells after pcripheral ncrve transplantation into the retina of adult rats. Brain Res. 328: 349-354.

So, K.-F., and G. E. Schneider (1978) Abnormal recrossing retinotectal projections after superior colliculus lesions in newborn Syrian hamsters. J. Comp. Neurol. 186: 241-258.

So, K.-F., G. E. Schneider, and S. Ayres (1981) Lesions of the brachium of the superior colliculus in neonate hamsters: Correlations of anatomy with behavior. Exp. Neurol. 72: 379-400. 
Van Hooff, C. O. M., P. N. E. DeGraan, J. Boonstra, A. B. Oestreicher, M. H. Schmidt-Michels, and W. H. Gispen (1986) NGF enhances the level of protein kinase C substrate, B-50, in pheochromocytoma PCl 2 cells. Biochem. Biophys. Res. Commun. 139: 644-651.

Willard, M., W. M. Cowan, and R. Vagelos (1974) The polypeptide composition of intra-axonally transported proteins: Evidence for four transport velocities. Proc. Natl. Acad. Sci. USA 71: 2183-2187.
Yoon, M. G., L. I. Benowitz, and F. Baker (1986) Tectal regulation of transported proteins in regenerating optic fibers of goldfish. Brain Res. 382: 339-351.

Zwiers, H., P. Schotman, and W. H. Gispen (1980) Purification and some characteristics of an ACTH-sensitive protein kinase and its substrate protein in rat brain membranes. J. Neurochem. 34: 16891699. 